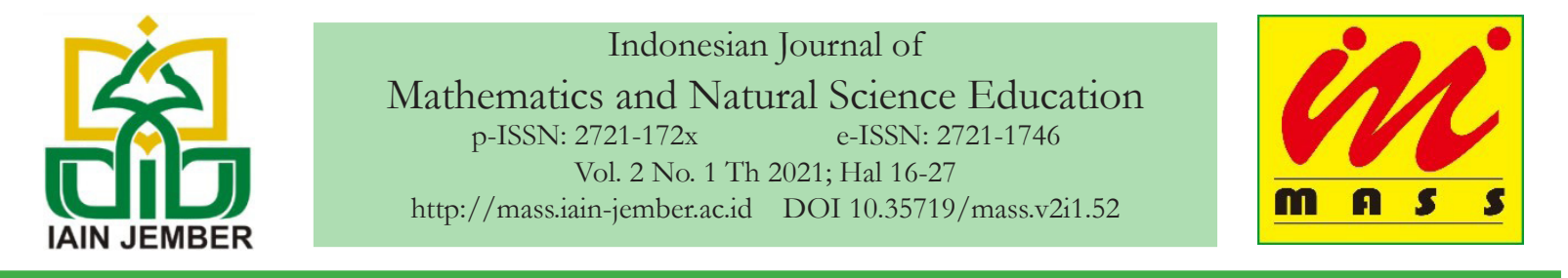

\title{
Pengembangan Media Belajar Buletin dalam Bentuk Buku Saku pada Materi Termokimia
}

\author{
Siti Muzzalifa ${ }^{1}$, Coryna Oktaviani ${ }^{1 *}$ \\ ${ }^{1}$ Program Studi Pendidikan Kimia, Universitas Malikussaleh, Aceh Utara \\ *E-mail: coryna.oktaviani@unimal.ac.id
}

\begin{abstract}
Abstrak
Penelitian ini bertujuan untuk mengetahui tingkat kelayakan media pembelajaran buletin dalam bentuk buku saku materi Termokimia kelas XI SMA Swasta Iskandar Muda terhadap tanggapan pendidik dan peserta didik. Jenis penelitian yang digunakan adalah penelitian pengembangan (R\&D) tipe Borg and Gall dengan pendekatan kualitatif. Penelitian ini mengadopsi model pengembangan Borg and Gall. Adapun tahapan yang dilakukan pada penelitian ini meliputi 6 tahap, yaitu (1) potensi dan masalah, (2) pengumpulan data, (3) desain produk, (4) validasi desain, (5) revisi desain, dan (6) uji coba produk. Pengumpulan data dilakukan di SMA Swasta Iskandar Muda dengan sampel yang diambil 2 orang pendidik kimia dan 31 orang peserta didik yang dipilih secara purposive sampling. Kelayakan media buletin dalam bentuk buku saku dinilai oleh 4 orang validator yaitu 2 validator materi diperoleh persentase rata-rata $75,8 \%$ dan 2 validator media (desain) diperoleh presentase rata-rata sebesar $84,0 \%$. Adapun hasil persentase tanggapan pendidik menunjukkan rata-rata sebesar $70,47 \%$ dan peserta didik sebesar $86,2 \%$. Berdasarkan hasil penelitian yang didapat bahwa media buletin dalam bentuk buku saku yang telah dikembangkan layak digunakan dalam proses pembelajaran materi Termokimia, dan memperoleh tanggapan yang positif dari pendidik dan peserta didik. Sehingga dapat disarankan untuk menggunakan buletin dalam bentuk buku saku bervariasi pada materi kimia lainnya.
\end{abstract}

Kata Kunci: Buku Saku, Buletin, Media, Termokimia

\section{PENDAHULUAN}

Media merupakan bagian dari komponen pembelajaran, manfaat dan fungsi media dalam pembelajaran sangat dirasakan baik oleh tenaga pendidik maupun peserta didik. Keberhasilan media dalam meningkatkan kualtias belajar peserta didik ditentukan pada bagaimana kemampuan pendidik dalam memilih media yang akan digunakan (Mahnun, 2012). Media pembelajaran adalah seluruh alat dan bahan yang dapat dipakai untuk tujuan pendidikan berupa media audio, media visual, media audio-visual maupun media cetak dan sebagainya. Media pembelajaran bukan hanya sekedar informasi beserta alatnya, akan tetapi juga proses mempeserta didikinya, sebab informasi atau pesan yang diketahui hasil pemberitahuan orang lain tidak akan menjadikan informasi tersebut menjadi bermakna dalam hidupnya (Sanjaya, 2012).

Alat bantu yang digunakan guru dalam pembelajaran untuk mencapai tujuan tertentu dinamakan media pembelajaran (Retno, 2015). Media pembelajaran yang ingin dicapai bertujuan 
untuk meningkatkan minat dan proses belajar mengajar yang aktif. Pembelajaran kimia banyak tidak disukai, masih sering dianggap sulit dan masalah bagi peserta didik. Banyaknya peserta didik menggangap pelajaran kimia tidak dibutuhkan dalam kehidupan sehari-hari sehingga enggan untuk mempelajarinya. Pahadal tanpa disadari banyak sekali kejadian disekitar, bahkan dalam tubuh manusia terjadi reaksi kimia secara alami dari bangun tidur hingga tidur lagi. Bernafas dengan menghirup oksigen yang terjadi secara alami oleh saluran pernafasan dan aktifitas lainnya yang sering dilakukan dalam kehidupan seharihari dapat dipelajari dalam pembelajaran kimia.

Menurut kamus Besar Bahasa Indonesia, buletin merupakan majalah sederhana yang tipis dan berisi uraian singkat, diterbitkan untuk kalangan sendiri (biasanya untuk lembaga atau organisasi). Pada dasarnya buletin ini termasuk dalam jenis jurnal pada ilmu komunikasi. Namun dengan fungsinya yang menyampaikan pesan dan informasi serta sifatnya yang mendidik, maka buletin dapat dikatakan media pembelajaran (Putri, 2015). Buku saku adalah buku berukuran kecil yang dapat disimpan dalam saku dan mudah dibawa kemana-mana. Buku saku yang dikembangkan melalui penelitian ini berukuran lebih kecil dibandingkan buku pelajaran yang beredar selama ini sehingga mudah dibawa kemana-mana dan berisi uraian materi kimia tentang termokimia. Selain itu untuk menarik minat baca siswa maka dilengkapi dengan banyak gambar dan warna. Siswa cenderung menyukai bacaan dengan banyak gambar dan warna (Masita, 2018).

Seiring dengan perkembangan zaman dan teknologi terkhususnya teknologi informasi dengan berbagai jenis dan bentuk dari media pembelajaran yang kerap digunakan oleh pendidik untuk dijadikan sumber ilmu pengetahuan bagi peserta didik. Teknologi informasi yang dipakai untuk sumber ilmu pengetahuan bisa berupa buku, buku saku, koran, majalah dalam bentuk buku saku yang berisi perhitungan serta contoh atau gambaran dari materi terserbut dalam bentuk cacatan kecil yang memudahkan peserta didik membaca dan membawanya kapan dan dimana saja terutama dalam materi Termokimia.

Buku saku adalah buku berukuran kecil yang dapat disimpan dalam saku dan mudah dibawa kemana-mana (Wejasu, 2017). Dengan adanya perkembangan teknologi sangatlah membantu dalam dunia pendidikan tetapi tidak semua sekolah mengizinkan mengunakan alat pembelajaran disetiap waktu terutama saat disekolah. Menurut Pramika (2018) pemilihan media belajar yang tepat akan berimbas pada keberhasilan pengajaran yang dilakukan pendidik. Pendidik hendaknya bisa cermat dan teliti dalam memilih alat/bahan ajar yang digunakan selama proses mengajar. Hal ini juga dikarenakan, apabila alat/bahan ajar yang digunakan menarik bagi peserta didik maka akan termotivasi untuk membaca buku dan belajar atas dorongan dari 
dirinya sendiri (belajar secara mandiri).

Pemilihan materi Termokimia ini dikarenakan peneliti sudah melihat bagaimana situasi saat pembelajaran berlangsung saat peneliti melakukan Praktik Pengalaman Lapangan (PPL) pada tahun lalu. Seringnya terjadi miskonsepsi oleh peserta didik adalah materi termokimia, hal ini dibuktikan dengan rendahnya minat dan prestasi belajar peserta didik yaitu dibawah 75 . Dimana hasil nilai dari kognitif, afektif dan psikomotorik dipeloreh nilai ratarata keseluruhan sebesar 73,1 yang peneliti peroleh saat peneliti mengajar saat praktik pengalaman lapangan (PPL). Dalam hal ini Sugiawati (2013) telah membuktikan pada penelitiannya bahwa, apabila diberikan beberapa reaksi dan diminta mengidentifikasi satu persatu persamaan reaksi tersebut serta masih kurangnya pemahaman konsep mengenai perhitungan $\Delta \mathrm{H}$ reaksi. Terdapat kecenderungan salah dalam menjawab soal-soal tersebut. Pemahaman siswa pada materi termokimia masih kurang dengan ketuntasan kelas mencapai kurang lebih $40 \%$ dibandingkan dengan materi yang lain, sehingga nilai ketuntasan masih perlu ditingkatkan.

Media yang akan peneliti pakai yaitu media buletin dalam bentuk buku saku yang dapat melihat tanggapan pendidik dan peserta didik pada materi Termokimia. Menurut Putri dalam Sanaky (2015), buletin dapat dikatakan sebagai media pembelajaran, hal ini dikarenakan buletin dapat digunakan untuk menyampaikan pesan dari sumber ke penerima. Media buletin dalam bentuk buku saku yang digunakan peneliti berukuran sekitar $13 \times 9 \mathrm{~cm}$ dalam ukuran kecil, ringan, dan bias disimpan disaku. Berisi materi Termokimia yang telah dirangkum oleh peneliti serta diberi contoh gambar yang sering terjadi dalam kehidupan sehari hari dan juga terdapat konsep perhitungan sesuai konsep matetri.

Media buletin ini segaja didesain sesuai standar sebagai alat bantu pembelajaran mengingat terdapat beberapa sekolah kekurangan buku sains terkhususnya kimia sehingga pada satu meja hanya terdapat satu buku cetak (panduan). Pembelajaran kimia untuk materi termokimia memerlukan media pembelajaran yang menarik untuk meningkatkan minat dan prestasi belajar peserta didik sehingga memperoleh hasil belajar yang memuaskan.

Penerapan buletin dalam bentuk buku saku merupakan salah satu upaya yang dapat dilakukan oleh pendidik untuk menambah sumber belajar peserta didik dan menarik minat belajar peserta didik terhadap materi termokimia yang kompleks. Penerapan media ini juga dapat memfasilitasi pembelajaran menjadi lebih menarik dan menyeluruh (Listiawati \& Qomariah, 2020).

Menurut penelitian dilakukan Sari, dkk. (2017), menyimpulkan bahwa secara keselu-ruhan minat belajar peserta didik dalam pembelajaran IPA di MTs Negeri Jember menggunakan buletin MALAPA (Mari Belajar IPA) tergolong baik dengan rata-rata persentase keseluruhan indikator minat sebesar $83,54 \%$. Hal ini dikuatkan 
oleh hasil penelitian Asyhari dan Silvia (2016), yang menyatakan bahwa respon peserta didik pada aspek penyajian materi yaitu $87,3 \%$ dikarenakan pada aspek penyajian materi indikator penilaian yaitu berupa penyajian materi, kemudahan memahami materi, ketepatan sistematika penyajian materi, kejelasan kalimat, kejelasan simbol dan lambang, kejelasan istilah dan kesesuaian contoh dengan materi yang sudah sesuai dengan indikator penilaian tiap aspek sedangkan penilaian pada aspek manfaat yaitu 80,3\%, indikator yang dinilai yaitu kemudahan belajar, ketertarikan menggunakan media buletin untuk pembelajaran IPA dan peningkatan motivasi belajar.

Menurut Dewi, dkk. (2014) dalam penelitian yang berjudul pengembangan majalah green sebagai media pembelajaran biologi pada materi sistem reproduksi manusia untuk siswa kelas XI IPA SMA menunjukkalan hasil akhir dari penelitian pengembangan ini adalah terciptanya majalah green yang layak digunakan. Hasil penilaian majalah green oleh ahli materi diperoleh presentase 78,57\% dengan kategori baik. Uji kelayakan oleh ahli media diperoleh presentase penilaian 76,92\% dengan kategori baik. Uji kelayakan oleh peer reviewer diperoleh presentase penilaian 91,67\% dengan kategori baik. Uji kelayakan oleh guru biologi diperoleh presentase penilaian 100\% dengan kategori baik. Sedangkan respon siswa terhadap majalah green adalah baik, ditunjukkan dengan rata-rata presentase penilaian $92,30 \%$ pada uji coba produk dan $85,15 \%$ pada uji coba pemakaian.
Hal itu juga dibuktikan oleh Hanum, dkk. (2017) dalam penelitiannya yang berjudul pengembangan media pembelajaran buletin pada materi hukumhukum dasar kimia kelas X SMA/MA di Banda Aceh menunjukkan bahwa hasil persentase tanggapan dari lima orang guru terhadap media buletin menunjukkan hasil positif, yakni sebesar 97,78\%. Hal ini menunjukkan bahwa guru sangat setuju terhadap pengembangan media buletin dan hanya $2,22 \%$ yang memberikan nilai negatif terhadap media tersebut. Guru memberikan nilai positif sebesar $97,78 \%$ terhadap pengembangan media buletin menunjukkan bahwa penggunaan media buletin ini dapat membantu guru dan peserta didik dalam proses belajar mengajar. Berdasarkan beberapa uraian di atas, maka peneliti bermaksud untuk mengembangkan media buletin dalam bentuk buku saku terhadap tanggapan pendidik dan peserta didik pada materi termokimia di Kelas XI SMA Swasta Iskandar Muda".

Adapun penelitian ini memiliki rumusan masalah, yaitu bagaimana kelayakan media pembelajaran buletin dan bagaimana tanggapan pendidik dan peserta didik terhadap media yang telah dikembangkan?

Sedangkan tujuan penelitian ini adalah untuk mengetahui tingkat kelayakan media pembelajaran buletin dalam bentuk buku saku pada materi Termokimia di kelas XI SMA Swasta Iskandar Muda terhadap tanggapan pendidik dan peserta didik. 


\section{METODE}

Penelitian ini menggunakan metode penelitian danpengembangan(Researchand development) dengan pendekatan kualitatif yang digunakan untuk menghasilkan suatu produk tertentu, dan mengetahui tingkat kelayakan produk. Model pengembangan yang digunakan yaitu model Borg and Gall dengan 6 tahap, yaitu (1) potensi dan masalah, (2) pengumpulan data, (3) desain produk, (4) validasi desain, (5) revisi desain, (6) uji coba produk. Model Borg and Gall dipilih karena model ini memiliki langkah-langkah yang jelas, sistematis, efektif dan efisien.

Penelitian pengembangan ini telah diselesaikan pada September 2019. Sampel dalam penelitian ini yaitu pendidik kimia dan peserta didik XI MIA SMA Swasta Iskandar Muda. Teknik pemilihan sampel menggunakan teknik purposive sampling. Instrumen yang digunakan berupa media buletin dalam bentuk buku saku dan lembar validasi yang diberikan kepada 4 validator, terdiri dari 2 orang validator materi dan 2 orang validator media yang sama-sama merupakan dosen program studi kimia, serta lembar angket respon guru dan peserta didik. Menurut Julianda (2017) menyatakan bahwa untuk menganalisis data yang diperoleh dari penyebaran angket maka menggunakan rumus persentase.

Instrumen penelitian yang digunakan pada penelitian ini berupa media buletin dan lembar angket. Media buletin adalah sarana sebagai salah satu sumber pembelajaran. Sedangkan lembar angket terdiri lembar validasi dan lembar penilaian kelayakan yang bertujuan untuk mengetahui tanggapan responden terhadap buletin dalam bentuk saku. Lembaran ini berisi beberapa pertanyaan dan cara pengisiannya yaitu memilih salah satu pilihan jawaban sehingga penilaian terhadap media buletin dalam bentuk buku saku dapat diberlakukan. Pilihan jawaban yang diberikan memiliki skor dari 1-5. Lebih lengkap dapat dilihat pada Tabel 1.

Tabel 1. Skala skor angket

\begin{tabular}{cc}
\hline Skor & Keterangan \\
\hline 1 & Sangat Kurang Baik \\
2 & Kurang Baik \\
3 & Cukup Baik \\
4 & Baik \\
5 & Sangat Baik \\
\hline
\end{tabular}

Kriteria penilaian terhadap kelayakan media buletin ini dinyatakan dalam persentase dan dihitung menggunakan rumus persentase. Pemberian skor persentase penilaian kelayakan media dapat dilihat pada Tabel 2.

Tabel 2. Skor Persentase Penialain Kelayakan Media

\begin{tabular}{ccc}
\hline No & Persentase (\%) & Kategori Penilaian \\
\hline 1 & $0-20$ & Sangat Tidak Layak \\
2 & $21-40$ & Tidak Layak \\
3 & $41-60$ & Cukup \\
4 & $61-80$ & Layak \\
5 & $81-100$ & Sangat Layak \\
\hline \multicolumn{3}{r}{} \\
\end{tabular}

\section{HASIL DAN PEMBAHASAN}

Penelitian pengembangan media buletin dalam bentuk buku saku terhadap tanggapan pendidik dan peserta didik pada materi Termokimia di kelas XI SMA Swasta Iskandar Muda merupakan penelitian jenis Research and Development (R\&D) yang dinilai oleh dua orang 
validator media dan dua orang validator materi.

Tahap analisis yang dilakukan dengan mengumpulkan informasi-informasi tentang pembelajaran, seperti melakukan analisis kebutuhan dan permasalahan peserta didik, menganalisis kurikulum, dan menganalisis karakteristik peserta didik. Peneliti melakukan analisis tersebut bertujuan untuk menetapkan permasalahan yang ada di lapangan sebagai sumber kajian awal peneliti dalam mengembangkan media buletin. Tahap analisis yang dilakukan dalam penelitian ini yaitu uji pendahuluan pada peserta didik tahun ajaran 2017/2018, wawancara pendidik bidang studi kimia serta melakukan studi kepustakaan terhadap bahan ajar

Tahap awal pengembangan media buletin untuk materi termokimia adalah mengkajii Kompetensi Dasar. Berdasarkan Kompetensi Dasar, materi termokimia yang harus dipahami peserta didik adalah peran termokimia dalam kehidupan sehari-hari, jenis-jenis reaksi termokimia, serta dapat membandingkan perubahan entalpi.

Tahap kedua pengembangan media buletin adalah mengumpulkan informasi mengenai bagaimana proses pembelajaran yang dilakukan oleh pendidik dan hasil pembelajaran yang diperoleh peserta didik setelah mempelajari materi termokimia. Adapun yang diperlukan dalam pembuatan media buletin adalah sebagai berikut: (1) Menyusun rencana dalam pem-buatan media buletin berdasarkan Kompetensi Dasar dan tujuan pembelajaran pada materi termokimia; (2) Mengumpulkan bahan-bahan tulisan dan berita kimia sesuai dengan konsep dari materi termokimia; (3) Penulisan konsep dan trik yang telah dikumpulkan dari berbagai referensi; (4) Mengedit dan mengkoreksi konsep; (5) Mendesain buletin mulai dari warna tema, gaya huruf, dan gambar yang dicantumkan dan (6) Mencetak buletin.

Proses desain buletin dengan menggunakan aplikasi Microsoft publisher. Aplikasi ini dipilih karena dalam aplikasi microsoft publisher sendiri sudah tersedia berbagai macam template. Sehingga bila ingin membuat suatu media seperti media buletin, peneliti hanya tinggal memilih template yang sudah disediakan, lalu mengeditnya sesuai dengan kemauan. Akan tetapi, peneliti juga harus mendesain, mengganti warna background, dan menambahkan gambar-gambar pada template tersebut. Karena apabila template tersebut tidak diedit dan tidak diganti warna serta desainnya, maka buletin yang telah dibuat akan terlihat tidak menarik.

Pemilihan desain buletin mempertimbangkan kondisi yang ada pada aplikasi. Desain awal buletin ini mengalami beberapa kali perbaikan, serta dapat banyak masukan dan saran dari dosen pembimbing dan penguji. Hasil penelitian yang dilakukan oleh Anjelita (2017) yang berjudul pembuatan buku saku sebagai media pembelajaran pada materi jamur kelas XSMA menyatakan media buku saku dinyatakan valid dan dapat digunakan sebagai media pembelajaran pada materi jamur dikelas X SMA. 
Hal ini juga diperkuat dengan hasil penelitian A'yun, dkk (2015) dimana penggunaan buletin komik diperoleh skor kemenarikan 3,32 dengan kategori sangat menarik, skor kemudahan 3,14 dengan kategori mudah, skor kemanfaatan 3,41 dengan kategori sangat bermanfaat dan keefektifan dengan persentase $81,48 \%$ siswa tuntas KKM.

Berdasarkan hasil tersebut dapat disimpulkan bahwa buletin komik yang dihasilkan sangat menarik, mudah digunakan, sangat bermanfaat, dan efektif sebagai media pembelajaran. Pada tahap ini ditentukan konsep dari media pembelajaran buletin yang akan dikembangkan. Media buletin didesain sebagai alat bantu pembelajaran yang dapat mempermudah peserta didik dalam memahami dan mengingat kembali materi yang telah disampaikan oleh pendidik serta dapat mempermudah peserta didik untuk belajar mandiri.

Media buletin didesain sebagai alat bantu pembelajaran yang menarik dan tidak membosankan. Buletin yang dikembangkan didesain berdasarkan: (1) Pemilihan materi, materi yang dipilih merupakan pengertian, perbedaan, jenisjenis, manfaat serta contoh yang diambil dalam kehidupan sehari-hari agar peserta didik bisa lebih memahaminya; Pemilihan gambar, gambar yang disajikan merupakan gambar yang berhubungan dengan contoh dari masing-masing materi yang terdapat dalam kehidupan seharihari dan (3) Warna background, warna background yang dipilih merupakan warna yang cerah serta berbeda pada setiap halamannya, selain itu warna pada masing-masing kolom disesuaikan dengan warna background agar terlihat kontras. Pemilihan warna tulisan kebanyakan memakai warna hitam supaya lebih jelas.

Setelah desain awal selesai, selanjutnya buletin diberikan masukan dan perbaikan oleh empat validator. Setelah proses perbaikan media maka dilakukan validasi terhadap media yang telah dikembangkan untuk mengetahui media yang telah dikembangkan layak digunakan atau tidak sebelum diuji coba kepada pendidik dan peserta didik. Aspek-aspek pada media yang divalidasi adalah aspek format media, visual, fungsi dan kejelasan media dalam penyajian konsep (Julianda, 2017). Hasil tahapan ini, selanjutnya peneliti mencetak massal produk yang dikembangkan. Sehingga dengan demikian, produk ini dapat dilakukan uji coba ke pendidik dan peserta didik. Beberpa hasil validasi media buletin dalam bentuk buku saku dapat dilihat pada gambar 1 dan gambar 2.

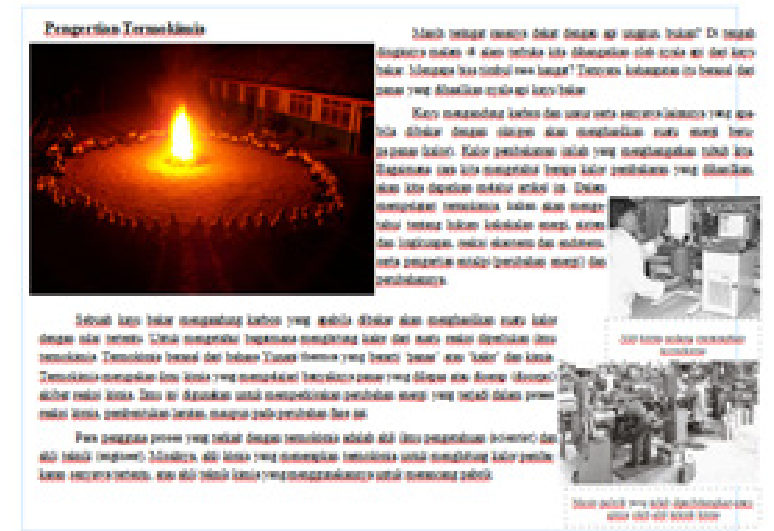

Gambar 1. Buku saku sebelum revisi

Media buletin dalam bentuk buku saku divalidasi oleh dua dosen ahli yang berkompetensi dalam bidang materi dengan tujuan untuk mendapatkan informasi, kritik serta saran agar media 


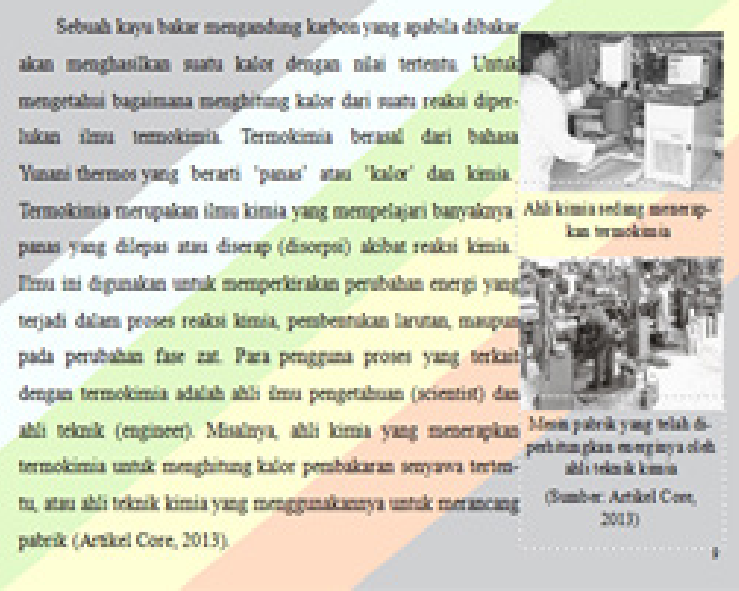

Gambar 2. Buku saku setelah revisi

dasar materi dan kesesuaian sajian dengan tuntutan pembelajaran yang terpusat pada peserta didik. Komentar dan saran dari ahli materi tersebut juga digunakan untuk proses penyempurnaan media sebelum dilakukan uji penggunaan media oleh pendidik dan peserta didik.

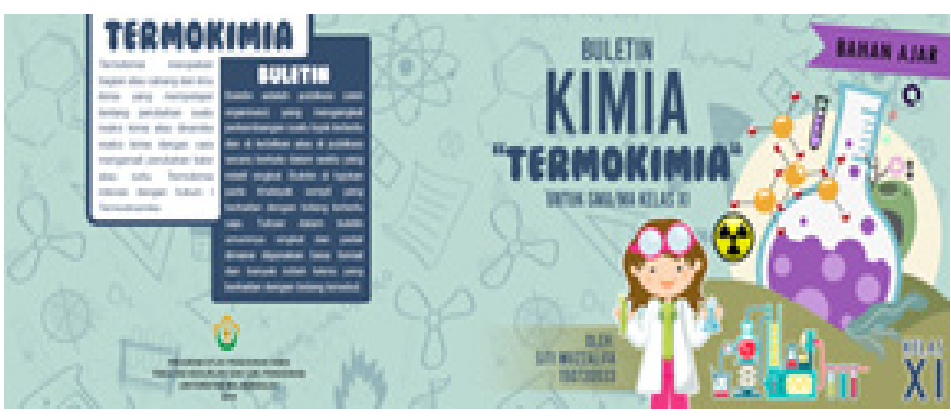

Gambar 3. Hasil produk (cover)

Gambar 3. Menunjukkan hasil produk akhir setelah divalidai oleh 4 orang validasi yaitu dua validator media dan dua validator materi serta tanggapan dari pendidik dan peserta didik. Hasil validasi ahli media oleh dua dosen menunjukkan bahwa \%rata-rata yang diperoleh dari validator satu yaitu $83 \%$ dan pada validator dua yaitu 85\%. Dengan demikian dapat diperoleh nilai \%rata-rata keseluruhan pada materi diperoleh $84 \%$.

Buletin dalam bentuk buku saku yang telah validasi oleh ahli materi dan ahli media, produk direvisi berdasarkan komentar dan saran dari ahli materi dan ahli media. Produk yang sudah direvisi tersebut digunakan dalam uji penggunaan media buletin dalam bentuk buku saku sebagai bahan ajar. Uji penggunaan media oleh pendidik dilakukan di SMA Swasta Iskandar Muda.

Uji penggunaan media yang kepada pendidik dilakukan dengan menggunakan lembar angket semi terbuka. Penggunaan angket semi terbuka, agar peneliti bisa mendapatkan tanggapan atau informasi dari pendidik dengan lebih jelas terhadap pengembangan media buletin. Pada penggunaan angket semi terbuka, setelah responden memilih jawabannya akan diberi kesempatan kepada untuk memberi alasan secara bebas sesuai jawaban yang dipilih.

Uji penggunaan media oleh pendidik menunjukkan hasil persentase tanggapan dari pendidik terhadap media buletin yang dikembangkan memberikan respon positif sebesar 70,47\%, persentase ini dapat menunjukan bahwa pendidik sangat setuju terhadap pengembangan media buletin. Sebanyak 29,53\% tidak setuju dengan media tersebut.

Hasil persentasetersebutmenunjukkan bahwa penggunaan media buletin ini dapat membantu pendidik dan peserta didik dalam proses belajar mengajar. Telah dibuktikan pada penelitian Saputra (2017) yang berjudul pembuatan buku saku materi keanekaragaman makhluk hidup di SMPIT Fajar Ilahi Batam tahun pelajaran 2016/2017 bahwa, hasil penilaian 
ahli materi diperoleh nilai validitas 80,00 yang termasuk dalam kategori valid, ahli media diperoleh nilai validitas 74,29 yang termasuk dalam kategori cukup valid, guru mata pelajaran IPA diperoleh nilai validitas 79,03 yang termasuk dalam kategori cukup valid dan penilaian siswa pada uji coba lapangan dengan nilai validitas 90,11 yang termasuk dalam kategori layak.

Selaras dengan hasil penelitian Imanda (2017) yang menyimpulkan bahwa pengembangan modul berbantuan media interaktif pada konsep dan reaksi-reaksi dalam asam basa layak digunakan dalam pembelajaran kimia. Hal ini diperoleh dari nilai dari validator ahli materi dan media sebesar $93 \%$, respons guru sebesar $84,65 \%$, dan respons peserta didik sebesar $83,81 \%$.

Uji penggunaan media yang diberikan kepada peserta didik berupa angket tertutup. Peserta didik diminta rumus persamaan yang sudah ditentukan. Data tersebut dapat dilihat pada gambar 4 . Item penilaian merupakan item yang harus diberikan tiap skor oleh peserta didik, dimana tiap item ialah: (1) Penyajian materi dalam media buletin; (2) Desain media buletin, (3) Penggunaan warna pada media buletin; (4) Kualitas gambar yang digunakan; (5) Kejelasan penggunaan bahasa/kalimat pada media buletin; (6) Bahasa yang digunakan mudah dipahami dan komunikatif; (7) Informasi yang disajikan berupa informasi actual, (8) Dapat dibaca dalam sekali duduk; (9) Materi disajikan secara singkat, padat dan jelas; (10) Mudah dibawa-bawa; (11) Dapat membantu proses pembelajaran; (12) Dapat mengetahui hasil praktikum secara umum; (13) Terdapat konsep-konsep pembelajaran; (14) Melatih latihan soal dan (15) Merupakan inti sari pemebalajaran.

Adapun semua item penilaian tersebut

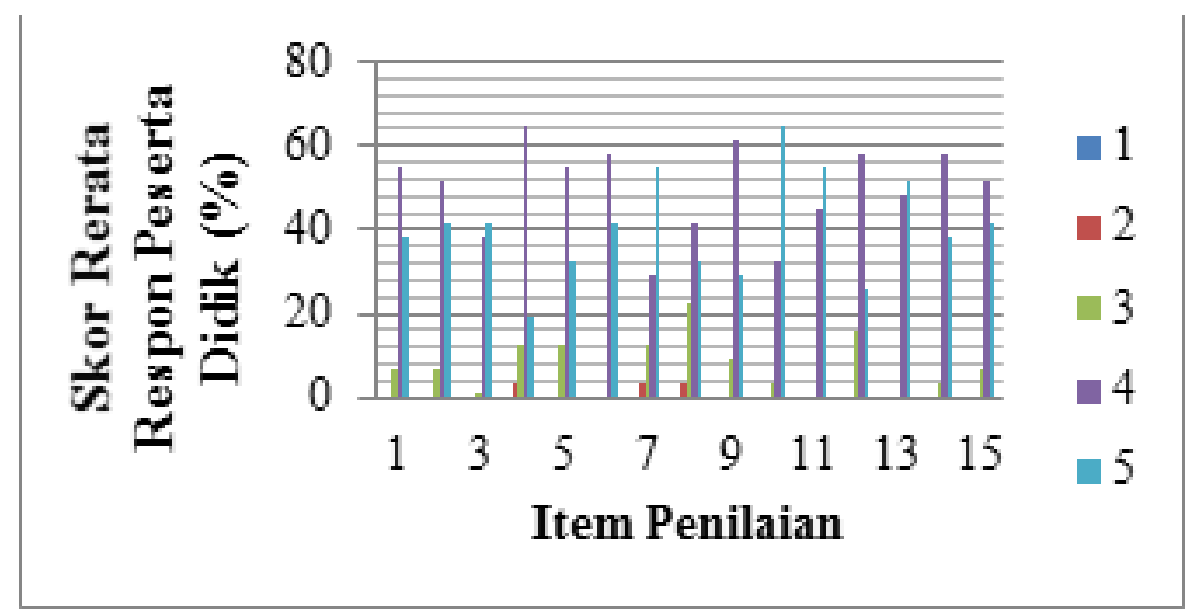

Gambar 4. Hasil respon peserta didik terhadap media buletin

untuk memberi tanggapan dengan cara memilih salah satu pilihan jawaban yang disediakan. Hasil tanggapan peserta didik diperoleh dengan cara menghitung frekuensi (skor) sehingga diperoleh nilai rata-rata setiap poinnya menggunakan diberi nilai tiap itemnya oleh peserta didik sebanyak 31 orang, sehingga memperoleh tiap itemnya dengan kategori sangat baik. Jumlah item yang perlu isi ialah 15 item dengan jumlah peserta didik 31 orang. Hasil tanggapan peserta didik terhadap 
media buletin yang dikembangkan sangat baik dengan rata-rata skor sebesar 86,2\%. Maka dapat dikatakan bahwa media visual buletin sebagai buku saku dengan materi Termokimia yang dikembangkan peneliti mendapatkan respon positif dari siswa.

Diketahui pula bahwa media ini sangat menarik dan penggunaan bahasa/kalimat pada media buletin mudah dipahami, sehingga selain dapat memotivasi peserta didik dalam belajar juga dapat mempermudah peserta didik dalam mempelajari materi Termokimia yang merupakan salah satu materi yang sulit dipahami oleh peserta didik kelas XI semester I. Hal ini diperkuat oleh penelitian Reza, dkk (2017) yang berjudul pengembangan media pembelajaran dalam bentuk buku saku digital berbasis android materi ajar gerak dan gaya di SMK 1 Kedungwuni membuktikan bahwa pengujian validasi produk aplikasi media diperoleh skor 69 dengan presentase interval penilaian media 75\% (Keriteria Setuju/Layak). Sedangkan hasil uji tanggapan pengguna diperoleh skor 1967 dengan presentase interval penilaian kelayakan media yaitu 80,87\% (Keriteria Setuju/Layak).

Berdasarkan data yang telah diperoleh dapat disimpulkan bahwa media pembelajaran yang telah dikembangkan layak dan memperoleh tanggapan yang positif dari pendidik dan peserta didik.

\section{SIMPULAN}

Berdasarkan hasil dari penelitian yang telah dilakukan dapat disimpulkan bahwa media buletin dalam bentuk buku saku layak digunakan dalam proses pembelajaran. Adapun tanggapan pendidik terhadap media buletin dalam bentuk buku saku adalah sebesar 70,47\%. Selanjutnya, tanggapan peserta didik terhadap media buletin dalam bentuk saku memperoleh nilai rata-rata sebesar $86,2 \%$. Hal ini berarti bahwa media pembelajaran yang telah dikembangkan memperoleh tanggapan yang positif dari pendidik dan peserta didik. Sehingga dapat disarankan untuk menggunakan buletin dalam bentuk buku saku bervariasi pada materi kimia lainnya.

\section{DAFTAR PUSTAKA}

Anjelita, Rita. Syamswisna, dan Ariyati, Eka. (2017). Pembuatan Buku saku sebagai Media Pembelajaran pada Materi Jamur Kelas X SMA. Tesis. Pontianak: P.MIPA FKIP Untan Pontianak

Asyhari, A. dan Silvia, H. (2016). Pengembangan Media Pembelajaran Berupa Buletin dalam Bentuk Buku Saku untuk Pembelajaran IPA Terpadu. Jurnal Ilmiah Pendidikan Fisika Al-BiRuNi. Vol. 05 No. 1.

A'yun, Q., Rahman, A., dan Maharta, N. (2015). Pengembangan Media Pembelajaran Buletin Komik Berbasis Scientific Approach Pada Pembelajaran IPA Terpadu. Jurnal Pembelajaran Fisika. Vol. 3 No. 4 Hal 115-125.

Dewi, N.A., dan Warso, A.W.D.D. (2014). Pengembangan Majalah Green Sebagai Media Pembelajaran Biologi pada Materi Sistem Reproduksi Manusia untuk Siswa Kelas XI IPA SMA. JUPEMASI-PBIO Vol. 1 No. 1

Hanum, L., Ismayani, A., dan Rahmi, R. (2017). Pengembangan Media Pembelajaran Buletin pada Materi Hukum-Hukum Dasar Kimia Kelas X SMA/MA di Banda Aceh. Jurnal IPA dan Pembelajaran IPA (JIPI). Volume 1 No 1

Imanda, R. Khaldun, I. dan Azhar. (2017). Pengembangan Modul Pembelajaran 
Kimia SMA Kelas XI PAda Materi Konsep dan Reaksi-reaksi dalam Larutan Asam Basa. Jurnal Pendidikan Sains Indonesia. Vol. 5 No.2

Julianda, M., Rusman, dan Habibati.(2017). Pengembangan Media Pembelajaran Berbentuk Buletin pada Materi Koloid di Kelas XI SMA Negeri 12 Banda Aceh. Jurnal Ilmiah Mahasiswa Pendidikan Kimia (JIMPK). Vol. 2 No.1

Listiawati, E., \& Qomariah, N. (2020). Pengembangan Media Pembelajaran Video Bus Math (Business Mathematic) Pada Materi Barisan dan Deret. Indonesian Journal of Mathematics and Natural Science Education, 1(2), 136-149. https://doi.org/10.35719/mass.v1i2.30.

Mahnun, Nunu.(2012). Media Pembelajaran (Kajian terhadap Langkah-langkah Pemilihan Media dan Implementasinya dalam Pembelajaran). Jurnal Pemikiran Islam. Vol. 37 No. 1

Masita, Mariana dan Wulandari, Desi. (2018). Pengembangan Buku Saku Berbasis Mind Mapping pada Pembelajaran IPA. Jurnal Kreatif. Vol. 8 No. 1

Petrucci, Ralph H., Hardwood, William S., dkk. (2011). Kimia Dasar Prinsip-prinsip $\mathcal{E}$ Aplikasi Modern. Jakarta: Erlangga

Purnomo, D. (2015). Majalah ataupun Buletin merupakan Komunikasi Massa Untuk Menyampaikan Pesan Kepada Masyarakat. Jakarta Timur: Badan Pembinaan Hukum Nasional

Pramika, D., dan Widalismana, M., (2018). BukuSaku sebagai MediaPembelajaran Mamtematika Ekonomi di Program Studi Pendidikan Akutansi FKIP UNIVERSITAS PGRI PALEMBANG. Jurnal Pendidikan Ekonomi UM Metro, Vol. 6 No. 1

Putri, N.R., Kurniawan. E.S., \&Fatmaryanti, S.D. (2015). Pengembangan Buletin Pembelajaran Fisika Pokok Bahasan Gerak Melingkar pada Siswa Kelas X IPA SMA Negeri 3 Purworejo Tahun Pelajaran 2014/2015. Jurnal Radiasi, 06(1)

Retno, A.T.P., Saputro, S, dan Utami, B. (2015). Pengembangan Media Pembelajaran Buletin dalam Bentuk
Buku Saku Berbasis Hirarki Konsep untuk Pembelajaran Kimia Kelas XI Materi Hidrolisis Garam. Jurnal Pendidikan Kimia (JPK), Vol.4 No. 2

Reza, M.F.A. dan Purwanti, D. (2017). Pengembangan Media Pembelajaran Dalam Bentuk Buku Saku Digital Berbasis Android Materi Ajar Gerak Dan Gaya Di SMK 1 Kedungwuni. Edu Komputika, Vol. 1 No. 1

Sanaky, AH. Hujair. (2009). Media Pembelajaran. Yogyakarta: Safiria Insan Press.

Sanjaya, W. (2012). Media Komunikasi Pembelajaran. Jakarta: Kencana

Saputra,H.dan Sari N.P. (2017).Pembuatan Buku Saku Materi Keanekaragaman Makhluk Hidup Di Smpit Fajar Ilahi Batam Tahun Pelajaran 2016/2017. Cahaya Pendidikan, Vol.4 No. 1

Sari, R.H., Rif'ati D., dan Pramudya Dwi A.P. (2017). Pengembangan Buletin Mari Belajar IPA (MALAPA) pada Pembelajaran IPA di MTs Negeri 2 Jember. Jurnal Pembelajaran Fisika, Vol.6 No. 1

Sugiawati, V.A. (2013). Penggunaan Strategi Konflik Kognitif Dalam Pembelajaran Tps Untuk Mereduksi Miskonsepsi Siswa Pada Materi Termokimia. Jurnal Nalar Pendidikan, Vol. 1 No. 1

Sutrisno. (2016). Berbagai pendekatan dalam pendidikan nilai dan Pendidikan Kewarnegaraan. Jurnal Dimensi Pendidikan dan Pembelajaran, Volume 5.

Wejasu, C.L., (2017). Pengembangan Media Pembelajaran berupa Buletin dalam Bentuk Buku Saku dengan Model Dick and Carey. Skripsi (Internet), https:// www.academia.edu).

\section{PROFIL SINGKAT}

Siti Muzzalifa lahir di Lhokseumawe, 26 Oktober 1997 yang merupakan anak pertama dari tiga bersaudara. Ia menempuh pendidikan SD di SD Swasta Al-Alaq dari tahun 2003-2009, SMP Negeri 
1 Dewantara dari tahun 2009-2012, SMA

Negeri 1 Dewantara dari tahun 2012-2015

dan masuk ke perguruan tinggi di daerah tempat tinggalnya yaitu di Universitas Malikussaleh mengambil jurusan pendidikan kimia dari tahun 2015 sampai tahun 2019 (selesai). 